\title{
Penerapan Model Cooperative Learning Tipe Stad untuk Meningkatkan Kemampuan Komunikasi Peserta Didik
}

\author{
Zaenul Slam \\ UIN Syarif Hidayatullah Jakarta \\ Email:zaenul_slam@yahoo.com
}

Naskah diterima: 28 November 2019, direvisi: 5 Desember 2019, disetujui: 27 Desember 2019

\begin{abstract}
The learning process that occurs in schools at the moment emphasizes more on Hard Skills and less emphasis on Soft Skills. This is due to the fact that in practice learning done in schools there are still many that run as is where the learning is still transferring knowledge from teachers to students, so to overcome these problems the Models of Cooperative Learning Type Student Teams Acbievement Division (STAD) is applied in the learning process carried out by the teacher with the aim of developing aspects of Soft Skills especially in the communication skills of students. This study uses qualitative and quantitative approaches with classroom action research methods. The stages in this study include the stages of planning, implementing actions, observations, and reflections. Data obtained in this study includes activity observation sheets the teacher, and the observation sheet of students 'activities.The results of observations of students' communication abilities in the first cycle of actions obtained enough categories (65.72\%) and in the second cycle of actions experienced an increase that is obtained a good category (81.71\%). It was concluded that by applying the models of Cooperative Learning Type STAD in Social Sciences learning can improve students' communication skills.
\end{abstract}

Keywords: Cooperative Learning Type STAD, Soft Skills, Communication.

\begin{abstract}
Abstrak
Proses pembelajaran yang di sekolah saat ini pada umumnya lebih menekankan pada Hard Skills dan kurang menekankan kepada Soft Skills. Hal ini disebabkan karena dalam praktiknya pembelajaran yang dilakukan di sekolah masih banyak yang berjalan apa adanya yang mana pembelajarannya masih transfer pengetahuan dari guru kepada siswa. Untuk mengatasi permasalahan tersebut diterapkan model Cooperative Learning Tipe Student Teams Acbievement Division (STAD) dalam proses pembelajaran untuk mengembangkan aspek Soft Skills, khususnya dalam kemampuan komunikasi peserta didik. Penelitian ini menggunakan pendekatan kualitatif dan kuantitatif dengan metode penelitian tindakan kelas. Adapun tahapan dalam penelitian ini meliputi tahapan perencanaan, pelaksanaan tindakan, observasi, dan refleksi. Data yang diperoleh dalam penelitian ini meliputi lembar observasi aktivitas guru, dan lembar observasi aktivitas peserta didik. Hasil observasi kemampuan komunikasi peserta didik pada tindakan siklus I diperoleh katagori cukup $(65,72 \%)$ dan pada tindakan siklus II mengalami peningkatan yaitu diperoleh katagori baik (81,71\%). Berdasarkan hasil observasi dapat disimpulkan bahwa dengan menerapkan model Cooperative Learning Tipe STAD pada pembelajaran Ilmu Pengetahuan Sosial dapat meningkatkan kemampuan komunikasi peserta didik.
\end{abstract}

Kata Kunci: Cooperative Learning Tipe STAD, Soft Skills, Komunikasi. 


\section{PENDAHULUAN}

Undang-Undang No. 20 pasal 3 Tahun 2003 tentang Sistem Pendidikan Nasional menyatakan bahwa pendidikan nasional berfungsi mengembangkan kemampuan dan membentuk watak serta peradaban bangsa yang bermartabat dalam rangka mencerdaskan kehidupan bangsa, bertujuan untuk berkembangnya potensi peserta didik agar menjadi manusia yang beriman dan bertakwa kepada Tuhan Yang Maha Esa, berakhlak mulia, sehat, berilmu, cakap, kreatif, dan menjadi warga yang demokratis serta bertanggung jawab. Sejalan dengan tujuan dan fungsi pendidikan tersebut, dapat dilihat bahwa tujuan memperoleh pendidikan adalah untuk mengembangkan potensi peserta didik.

Salah satu hal utama bagi suatu negara untuk terus maju adalah dengan adanya pendidikan yang memberikan dampak baik bagi negara agar negara tersebut memiliki kehormatan di mata dunia. Pendidikan dituntut untuk terus berkembang sesuai dengan perkembangan zaman yang mana saat ini sudah semakin canggih. Perubahan komposisi kemampuan berpikir tingkat tinggi pada keterampilan Abad 21 sebagai konsekuensi perubahan tuntutan-tuntutan standar-standar pendidikan yang menghendaki lulusan yang kritis, kreatif, komunikatif, dan kolaboratif harus menjadikan kebutuhan pendidikan.

Pendidikan merupakan usaha sadar manusia untuk memanusiakan manusia ke arah yang lebih baik. Namun proses pembelajaran yang terjadi di sekolah saat ini lebih menekankan aspek pengetahuan atau boleh dikatakan lebih menekankan kepada Hard Skills dan kurang menekankan kepada Soft Skills. Hal ini disebabkan karena dalam praktiknya pembelajaran yang dilakukan di sekolah masih banyak yang berjalan apa adanya yang mana pembelajarannya masih memindahkan pengetahuan dari guru kepada siswa. Seperti yang disampaikan Indrajati (2001: 27) bahwa "sebagian besar metode dan suasana pembelajaran di kelas yang digunakan para guru masih analog dengan kegiatan menabung". Dengan pembelajaran seperti ini, peserta didik hanya disiapkan untuk mendengarkan, mau menerima seluruh informasi dan mentaati segala peraturan gurunya yang mengakibatkan peserta didik tidak memiliki keberanian untuk mengemukakan pendapat, tidak kreatif apalagi untuk berpikir inovatif dan problem solving.

Selain menggunakan metode "gaya menabung", nampaknya para guru sering pula menggunakan metode pembelajaran dengan sistem persaingan misalnya dalam mengerjakan tugas-tugas Lembar Kerja Siswa (LKS).

Nasution (2004: 147-148) menjelaskan beberapa keburukan implementasi pembelajaran dengan sistem persaingan sebagai berikut: Pertama, peserta didik melakukan persaingan dengan tujuan memperoleh angka atau pujian perorangan. mereka belajar semata-mata didorong oleh motivasi ekstrinsik dan kepentingan perseorangan saja. Kedua, persaingan dapat menimbulkan perselisihan dan pertengkaran dalam kelas yang memburukkan hubungan antara peserta didik. Tujuan mengalahkan lawan dan memperoleh kemenangan untuk sendiri merusak suasana. Ketiga, yang menang dalam persaingan merasa dirinya terpandai dan menganggap orang lain bodoh. Dampak negatifnya timbul gejala-gejala superioritas padanya. Mereka merasa lebih dan orang lain lemah. Sifat ini merusak pribadi anak itu sendiri. Keempat, peserta didik yang kalah dalam persaingan menderita rasa kegagalan (sence of failure) prusatasi dan rendah diri. Dengan menggunakan model-model pembelajaran semacam itu akan menyulitkan guru menghadirkan peserta didik yang komunikatif sebagai salah satu tuntutan keterampilan abad 21.

Berdasarkan persoalan pembelajaran tersebut, nampaknya pembelajaan tersebut masih menggunakan paradigma lama pembelajaran, yakni teacher centre belum student centre. Masih teaching belum learning. Oleh karena itu, proses belajar mengajar sejatinya dilakukan guru sesuai dengan rencana pembelajaran yang telah disusun sehingga guru mempunyai tujuan pembelajaran yang jelas, mempunyai metode, dan model yang efektif, menguasai materi yang akan disampaikan sehingga pembelajaran akan dipahami dengan baik oleh peserta didik.

Dalam pembelajaran Ilmu Pengetahuan Sosial, model pembelajaran memiliki kedu- 
dukan yang sangat strategis dalam proses pembelajaran dimana dengan adanya model pembelajaran ini guru dapat mengkondisikan peserta didik dengan baik melalui cara mengajar guru yang inovatif, kreatif, efektif dan menyenangkan sehingga Soft Skills peserta didik dapat dikembangkan dengan baik.

Model pembelajaran menurut Komalasari (2010: 57) bahwa model pembelajaran merupakan bentuk pembelajaran yang tergambar dari awal sampai akhir yang disajikan secara khas oleh guru.

Dari pendapat tersebut dapat dijelaskan bahwa model pembelajaran merupakan suatu kerangka yang disusun secara sistematis oleh guru dengan bentuk pembelajaran yang tergambar dari awal sampai akhir dapat diketahui yang nantinya akan dijadikan sebagai acuan ketika pembelajaran berlangsung untuk mencapai suatu tujuan pembelajaran yang diharapkan serta menciptakan suasana pembelajaran yang efektif dan efisien agar tercapainya perubahan pada peserta didik.

Anita Lie (2007: 28) menyebut Cooperative Learning dengan istilah pembelajaran gotong royong, yaitu sistem pembelajaran yang memberikan kesempatan kepada peserta didik untuk bekerjasama dengan peserta didik lain dengan tugas-tugas terstruktur. Lebih jauh dikatakan Cooperative Learning hanya berjalan kalau sudah terbentuk suatu kelompok atau suatu tim yang didalamnya peserta didik bekerja secara terarah untuk mencapai tujuan yang sudah ditentukan dengan jumlah anggota kelompok pada umumnya terdiri dari 4-6 orang saja.

Roger dan David Johnson (dalam Anita Lie, 2007: 31) menyatakan bahwa tidak semua kerja kelompok bisa dianggap Cooperative Learning. Untuk mencapai hasil yang maksimal, lima unsur unsur model Cooperative Learning dasar yang harus diterapkan yaitu: pertama, saling ketergantungan positif, berarti keberhasilan suatu karya sangat tergantung pada usaha setiap anggotanya. Semua orang bekerja demi tercapainya satu tujuan yang sama. Kedua, tanggung jawab perorangan, berarti walaupun bekerja sama dalam kelompok, namun tanggung jawab tetap dibebankan pada individu. Ketiga, tatap muka, berarti setiap kelompok diberi kesempatan untuk bertemu muka dan berdiskusi. Kegiatan ini akan menciptakan sinergi yang menguntungkan semua anggota. Keempat, komunikasi antar anggota, berarti proses komunikasi melatih peserta didik kapan harus bertindak sebagai pembicara yang baik dan kapan harus bertindak sebagai pendengar yang baik. Sehingga diharapkan tercipta suatu sikap menghargai pendapat orang lain. Kelima, evaluasi proses kelompok yang berarti evaluasi tidak perlu diadakan setiap kali ada kerja kelompok. Evaluasi ini dapat dilaksanakan selang beberapa waktu (misalnya bulan) setelah beberapa kali melaksanakan pembelajaran kooperatif.

Dengan cooperative learning akan mampu meningkatkan kemampuan diri atau soft skills siswa yang mana dengan model ini selain siswa meraih keberhasilan dalam belajar, juga bisa melatih siswa untuk memiliki kemampuan komunikasi seperti mengemukakan pendapat, presentasi laporan, dan memajangkan hasil kerja. Pentingnya keterampilan berkomunikasi ini dibelajarkan kepada peserta didik dalam mata pelajaraan Ilmu Pengetahuan Sosial melalui model ini karena keterampilan ini merupakan modal sosial menuju suksesnya seseorang pada abad ke-21 ini.

Model pembelajaran Cooperative Learning Tipe STAD dapat diyakini efektif sebagai modal utama suksesnya kehidupan anak bangsa Indonesia.

Slavin (dalam Shoimin, 2014: 186) menyatakan bahwa Cooperative Learning tipe STAD diterapkan dalam kelas melalui lima tahapan, yaitu: (a) presentasi kelas, (b) kerja kelompok, (c) kuis, (d) peningkatan nilai individu, (e) penghargaan kelompok.

Lickona (2012: 276-278) menunjukkan enam keuntungan kalau metode ini mampu dipraktikkan secara baik, yaitu: (1) melalui proses belajar kooperatif, peserta didik akan diajarkan bagaimana karakter-karakter kerjasama, (2) melalui proses belajar kooperatif, peserta didik dibantu untuk saling mengenal dengan cara membangun komunikasi di dalam kelas. (3) melalui proses belajar kooperatif, peserta didik diajari keterampilan dasar kehidupan dengan tujuan mampu mendengarkan 
pandangan-pandangan orang lain dan berkomunikasi secara efektif, (4) melalui proses belajar kooperatif, peserta didik akan diarahkan untuk memperbaiki pencapaian akademik, rasa percaya diri, dan penyikapan terhadap sekolah, (5) melalui belajar kooperatif, peserta didik diberikan tawaran-tawaran alternatif dalam pencatatan, yakni tidak ada pembeda antara si kaya dan simiskin atau si pandai atau si bodoh, mereka akan belajar bekerjasama serta memperdulikan orang lain, dan (6) melalui belajar kooperatif, peserta didik akan memiliki potensi untuk mengontrol efek negatif dan persaingan. Keenam keuntungan pembelajaran kooperatif tidak saja di dalam kelas, tetapi kelihatan pengaruhnya yang sangat signifikan, yaitu ketika para peserta didik melakukannya di luar kelas pada jam-jam latihan.

Berdasarkan hal di atas, keuntungan penerapan Cooperative Learning tipe STAD dapat meningkatkan Soft Skills, yang mana salah satunya adalah kemampuan komunikasi peserta didik dimana kemampuan komunikasi sangat penting untuk dimiliki oleh setiap individu. Dengan memiliki kemampuan komunikasi yang lebih baik akan memudahkan seseorang mencapai kesuksesan bagi kehidupannya.

Bahwa kemampuan komunikasi yang baik itu amat penting, dapat disimak dari hasil penelitian di Harvard University Amerika serikat Ibrahim (dalam Adisusilo, 2012: 79), kesuksesan hidup seseorang tidak ditentukan semata-mata oleh pengetahuan dan kemampuan teknis (hard skill) yang diperoleh lewat pendidikan, tetapi lebih oleh kemampuan mengelola diri yang didalamnya termasuk karakter dan orang lain (soft skill). Penelitian ini mengungkapkan, bahwa kesuksesan seseorang hanya ditentukan sekitar $20 \%$ oleh hard skill dan sisanya $80 \%$ oleh soft skill. Bahkan orang-orang tersukses di dunia bisa berhasil dikarenakan lebih banyak didukung kemampuan soft skill dari pada hard skill. Kemampuan komunikasi merupakan dimensi soft skill. Hal ini mengisyaratkan bahwa kemampuan komunikasi peserta didik sangat penting untuk dikembangkan.

Kata "komunikasi" berasal dari kata latin Cum, yaitu kata depan yang berarti dengan dan bersama dengan, dan Unus, yaitu kata bilangan yang berarti satu. Dari kedua kata itu terbentuk kata benda Communion yang dalam bahasa Inggris menjadi Communion dan berarti kebersamaan, persatuan, persekutuan, gabungan, pergaulan, hubungan

Menurut Hardjana (2003) komunikasi dapat didefinisikan sebagai proses penyampaian makna dalam bentuk gagasan atau informasi dari seseorang kepada orang lain melalui media tertentu.

Komunikasi merupakan merupakan proses penyampaian seseorang untuk menyampaikan suatu pesan kepada orang lain melalui berbagai media demi terpenuhi kebutuhan hidupnya dalam lingkungan masyarakat.

Kemampuan komunikasi merupakan hal yang penting dimiliki peserta didik, selain mencerminkan peserta didik itu aktif dalam proses pembelajaran di kelas kemampuan komunikasi juga merupakan suatu proses penyampaian makna, bahasa, perasaan dan pikiran yang dimilikinya sehingga peserta didik akan terus menggali lebih dalam informasi yang akan dan telah diperolehnya. Kemampuan komunikasi ini merupakan keterampilan sosial di mana siswa sebagai insan sosial yang baik harus memiliki kemampuan komunikasi baik di lingkungan kelas maupun di lingkungan yang lebih luas.

Mata pelajaran Ilmu Pengetahuan Sosial mendapatkan tanggung jawab dalam melahirkan seseorang yang memiliki kemampuan komunikasi. Mata Pelajaran Ilmu Pengetahuan Sosial memberikan dukungan dalam penguatan karakter dan jati diri bangsa yang mana modal insan sosial dalam bergaul dengan masyarakat global adalah kemampuan yang salah satunya kemampuan komunikasi.

Tujuan Mata Pelajaran Ilmu Pengetahuan Sosial ini adalah sebagai berikut: (1) membekali peserta didik dengan pengetahuan sosial yang berguna dalam kehidupan masyarakat, (2) membekali peserta didik dengan kemampuan mengenal pasti, menganalisis, dan menyusun alternatif pemecahan masalah sosial yang berlaku dalam kehidupan di masyarakat, (3) membekali peserta didik dengan kemampuan berkomunikasi dengan sesama warga masya- 
rakat \& dengan pelbagai bidang keilmuan serta pelbagai keahlian, (4) membekali peserta didik dengan kesadaran, sikap mental yang positif dan kehidupan yang menjadi sebahagian daripada kehidupan yang tidak dapat dipisahkan (5) membuat pelajar dengan keupayaan untuk membangunkan pengetahuan dan sains ilmu pengetahuan sosial selaras dengan perkembangan kehidupan, perkembangan dan teknologi.

Mata Pelajaran Ilmu Pengetahuan Sosial ini mengembangkan keterampilan yang ada dalam diri seorang sebagai insan sosial. Keterampilan yang dikembangkan salah satunya adalah keterampilan berinteraksi. Keterampilan tersebut dalam mata pelajaran Ilmu Pengetahuan Sosial sering kita kenal dengan Social Skill. Keterampilan berkomunikasi berkaitan dengan keterampilan-keterampilan warga masyarakat dalam berkomunikasi (bertanya, menjawab, dan berunding dengan santun) dan bekerja sama dengan orang lain.

Kemampuan komunikasi peserta didik yaitu: Pertama, kemampuan komunikasi verbal yang meliputi: melakukan diskusi, mempresentasikan hasil diskusi, menyampaikan pendapat, menjawab pertanyaan, menuliskan hasil akhir diskusi, menggunakan tata bahasa yang baik, dan pembicaraan singkat, jelas, dan mudah dipahami serta suara terdengar jelas. Kedua, kemampuan komunikasi nonverbal meliputi: melihat lawan bicara, ekspresi wajah yang ramah, dan gerakan tangan yang sesuai dengan kata-kata yang diucapkan.

Dapat dikatakan bahwa kemampuan komunikasi dalam Ilmu Pengetahuan Sosial ini dibelajarkan oleh guru untuk: (1) mendorong Peserta didik melakukan tukar pikiran dan/ atau perasaannya terkait kebutuhan kewarganegaraan yang membutuhkan komunikasi dan kolaborasi; dan (2) memberi penguatan verbal, gestural, aktivitas atas kreativitas/kreasi Peserta didik sebagai warganegara yang berhasil membangun komunikasi dan kolaborasi. Dengan demikian, mata pelajaran IPS ini dapat membentuk warga negara yang berkemampuan sosial dan yakin akan kehidupannya sendiri di tengah-tengah lingkungan sosial yang heterogen, yang pada gilirannya akan menjadi warga negara yang baik dan bertanggung jawab.

\section{METODE PENELITIAN}

Penelitian ini menggunakan pendekatan kualitatif dan kuantitatif. Pendekatan kualitatif menurut Creswell (dalam Darmadi, 2013: 286) mengatakan bahwa: "Pendekatan kualitatif adalah suatu proses penelitian dan pemahaman yang berdasarkan pada metodologi yang menyelidiki suatu fenomena sosial dan masalah manusia. Pada pendekatan ini, peneliti membuat suatu gambaran kompleks, meneliti katakata, laporan terinci dan pandangan responden, dan melakukan studi pada situasi yang alami."

Pendekatan kuantitatif menurut Sugiyono (2013: 23), karena data penelitian berupa angkaangka dan analisis menggunakan statistik. Metode kuantitatif digunakan apabila masalah merupakan penyimpangan antara yang seharusnya dengan yang terjadi, antara aturan dengan pelaksanaan, antara teori dengan praktik, antara rencana dengan pelaksanaan. Pendekatan kuantitatif adalah suatu pendekatan yang hasilnya berupa angka-angka untuk membandingkan sejauh mana peningkatan yang terjadi.

Metode penelitian yang diterapkan dalam desain penelitian ini adalah penelitian tindakan kelas. Penelitian Tindakan Kelas menurut Suharsimi dalam Daryanto (2011: 3) bahwa penelitian tindakan kelas merupakan paparan gabungan definisi dari tiga kata "penelitian, tindakan, dan kelas". Penelitian adalah kegiatan mencermati suatu objek, menggunakan aturan metodologi tertentu untuk memperoleh data atau informasi yang bermanfaat bagi peneliti atau orang-orang yang berkepentingan dalam rangka peningkatan kualitas di berbagai bidang. Tindakan adalah suatu gerak kegiatan yang sengaja dilakukan dengan tujuan tertentu yang dalam pelaksanaannya berbentuk rangkaian periode/siklus kegiatan. Sedangkan kelas adalah kelompok siswa yang dalam waktu yang sama dan tempat yang sama menerima pelajaran yang sama dari seorang guru yang sama.

Penelitian tindakan kelas bersifat siklus dimana dalam satu siklus terdiri dari beberapa tahap yakni perencanaan, pemberian tindakan, pengamatan dan refleksi. Dengan demikian, penelitian tindakan kelas merupakan salah satu kemampuan yang harus dimiliki oleh guru 
untuk menjaga profesionalitas kinerjanya. Kegiatan ini memungkinkan guru untuk meningkatkan kualitas pembelajaran yang bermuara pada peningkatan kualitas pendidikan nasional. Penelitian tindakan ini dilaksanakan selama dua siklus, setiap siklus merupakan rangkaian kegiatan yang saling berkaitan. Artinya pelaksanaan siklus II merupakan kelanjutan dan perbaikan dari pelaksanaan siklus I.

Subyek penelitian ini adalah seluruh peserta didik kelas IX B SMP Prakarya Santi Asromo tahun ajaran 2017/2018 berjumlah 32 orang, yang terdiri atas 18 orang perempuan dan 14 orang laki-laki.

Lokasi penelitian mengenai penerapan model Cooperative Learning Tipe STAD berbasis Soft Skills untuk meningkatkan kemampuan komunikasi peserta didik pada pembelajaran Ilmu Pengetahuan Sosial dilaksanakan di SMP Prakarya Santi Asromo yang beralamat di Desa Pasirayu Kecamatan Sindang Kabupaten Majalengka Provinsi Jawa Barat.

\section{HASIL PENELITIAN DAN PEMBAHASAN}

Deskripsi pelaksanaan pada siklus I dijelaskan sebagai berikut: Pertama, kegiatan pendahuluan, yaitu: (1) guru mengucapkan salam, (2) guru memeriksa kehadiran peserta didik, (3) guru mengaitkan materi sebelumnya, (4) guru mengajak peserta didik untuk bernyanyi lagu" Dari Sabang Sampai Merauke" yang bertujuan mengkondisikan suasana pembelajaran yang menyenangkan. Kedua, Kegiatan Inti, yaitu: (a) mengamati, peserta didik mengamati video tentang pembebasan Irian barat, (b) menanya, peserta didik diberi kesempatan untuk mengajukan pertanyaan di bawah bimbingan guru tentang perjuangan bangsa Indonesia merebut Irian Barat, peserta didik dibagi menjadi empat kelompok, dan setiap kelompok diberikan lembar kerja siswa (LKS). (c) mengumpulkan informasi, yaitu pelaksanaan Cooperative Learning tipe STAD, yaitu: penugasan menggunakan LKS untuk dikerjakan dalam kelompok masing-masing dengan pembagian: kelompok 1 membahas tentang perjuangan mengembalikan Irian Barat, kelompok 2 membahas tentang tahapan pelaksanaan operasi Mandala dan operasi-operasi pendaratan di Irian Barat, kelompok 3 membahas tentang perjanjian New York dan pengaruhnya terhadap penyelesaian Irian Barat, kelompok 4 membahas tentang arti penting Penentuan Pendapat Rakyat (PAPERA). Dalam kegiatan ini Peserta didik mencari informasi dari berbagai sumber, salah satunya membaca buku Ilmu Pengetahuan Sosial kelas 9. Berdasarkan informasi yang diperoleh, peserta didik dalam kelompoknya mengerjakan Lembar Kerja yang diberikan guru, (d) mengolah data dan informasi, yaitu pelaksanaan diskusi kelompok (peserta didik berdialog, secara mendalam untuk saling membantu, memahami materi pelajaran dengan anggota kelompok kemudian mencatat hasil diskusi), guru berkeliling sambil memperhatikan kelompok yang memerlukan bantuan, (e) mengkomunikasikan, yaitu perwakilan kelompok mempresentasikan hasil diskusi kelompok masing-masing, peserta didik mendengar tanggapan guru terhadap hasil kerjanya, guru memberikan kuis atau pertanyaan kepada peserta didik, pada saat menjawab kuis tidak boleh saling membantu. Ketiga, Kegiatan Penutup, yaitu: (a) guru bersama peserta didik membuat kesimpulan hasil pembelajaran, (b) guru memberikan tugas untuk membaca materi yang akan disajikan pada pada pertemuan selanjutnya tentang Tragedi Nasional, yaitu Peristiwa Madiun, (c) guru menutup pelajaran dan mengucapkan salam.

Hasil observasi kemampuan berkomunikasi peserta didik pada siklus I terlihat pada tabel 1 berikut.

Tabel 1 Kemampuan Berkomunikasi Peserta Didik Pada Siklus I

\begin{tabular}{|c|l|c|c|}
\hline No & $\begin{array}{l}\text { Komponen } \\
\text { Keterampilan Komunikasi } \\
\text { Peserta Didik }\end{array}$ & Jumlah & $\begin{array}{c}\text { Persentasi } \\
\text { dari 32 } \\
\text { Peserta Didik }\end{array}$ \\
\hline A & $\begin{array}{l}\text { Kemampuan } \\
\text { berkomunikasi verbal }\end{array}$ & 22 & $69 \%$ \\
\hline 1. & Melakukan diskusi & 22 & $69 \%$ \\
\hline 2. & $\begin{array}{l}\text { Mempresentasikan hasil } \\
\text { diskusi }\end{array}$ & 22 & $69 \%$ \\
\hline 3 & Menyampaikan pendapat & 20 & $63 \%$ \\
\hline 4 & $\begin{array}{l}\text { Menjawab pertanyaan } \\
\text { diskusi }\end{array}$ & 20 & $63, \%$ \\
\hline 5. & $\begin{array}{l}\text { Menuliskan hasil akhir } \\
\text { yang baik }\end{array}$ & 22 & $69 \%$ \\
\hline 7. & $\begin{array}{l}\text { Pembicaraan singkat, jelas } \\
\text { dan mudah dimengerti } \\
\text { serta terdengar dengan jelas }\end{array}$ & 20 & $63 \%$ \\
\hline \multicolumn{2}{|c|}{ Rata-rata \% KB 1 } \\
\hline
\end{tabular}




\begin{tabular}{|c|l|c|c|}
\hline B. & $\begin{array}{l}\text { Kemampuan } \\
\text { Berkomunikasi Nonverbal }\end{array}$ & & \\
\hline 8. & Melihat lawan bicara & 22 & $69 \%$ \\
\hline 9. & Ekpresi wajah yang ramah & 20 & $63 \%$ \\
\hline 10. & $\begin{array}{l}\text { Menggerakan tangan } \\
\text { sesuai kata-kata yang } \\
\text { diucapkan. }\end{array}$ & 20 & $63 \%$ \\
\hline \multicolumn{3}{|c|}{ Rata-rata \% KB 2 } & $65 \%$ \\
\hline \multicolumn{2}{|c|}{ Rata-rata \% KB 1 dan KB 2 } & $65,72 \%$ \\
\hline
\end{tabular}

Secara grafis dapat dilihat peningkatannya pada grafis 1 berikut.

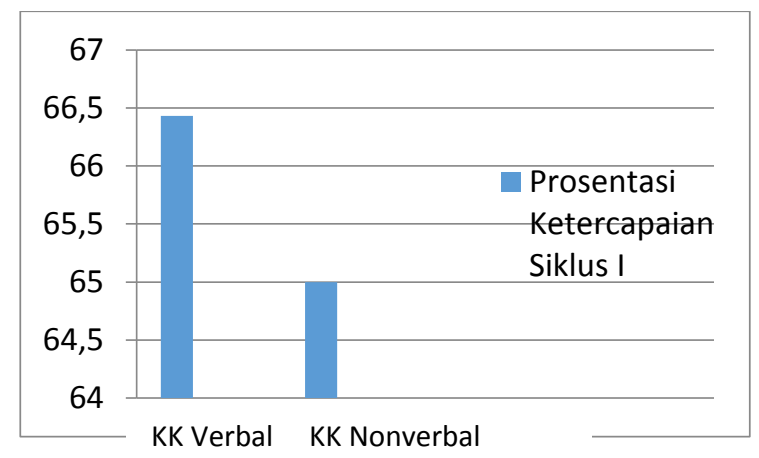

Karena masih adanya kekurangan pada siklus I dalam proses pembelajaran, yaitu para peserta didik terlihat belum punya tanggung jawab untuk memastikan bahwa teman satu tim mereka telah mempelajari materinya selama kegiatan Cooperative Learning tipe STAD, guru kurang efektif dalam melakukan pembimbingan kepada setiap kelompok dan kurangnya pemahaman peserta didik terhadap setiap langkah Cooperative Learning Tipe STAD dan hasil belajar peserta didik (kemampuan berkomunikasi peserta didik) belum mencapai target yang diharapkan, maka diperlukan pelaksanaan siklus II dengan beberapa perbaikan.

Tindakan pada siklus II dipaparkan sebagai berikut: Pertama, kegiatan pendahuluan, yaitu: (1) guru mengucapkan salam, (2) guru memeriksa kehadiran peserta didik, (3) guru mengaitkan materi sebelumnya, (4) guru mengajak peserta didik untuk bernyanyi lagu" Maju Tak Gentar" yang bertujuan mengkondisikan suasana pembelajaran yang menyenangkan dan kecintanaan terhadap tanah air Indoensia, (5) guru menyampaikan Tujuan Pembelajaran. Kedua, Kegiatan Inti, yaitu: (a) mengamati, peserta didik mengamati video tentang peristiwa Madiun, (b) menanya, peserta didik diberi kesempatan untuk mengajukan pertanyaan di bawah bimbingan guru tentang peristiwa madiun, peserta didik dibagi menjadi empat kelompok, dan setiap kelompok diberikan lembar kerja siswa (LKS). (c) mengumpulkan informasi, yaitu pelaksanaan cooperative learning tipe STAD, yaitu: penugasan menggunakan LKS untuk dikerjakan dalam kelompok masing-masing dengan pembagian: kelompok 1 membahas tentang apa yang menginspirasi Musso menggerakkan pemberontakan di Madiun, kelompok 2 membahas tentang bagaimana tanggapan rakyat secara umum dengan pemberontakan PKI di Madiun, kelompok 3 membahas tentang mengapa Madiun dipilih sebagai lokasi pemberontakan, kelompok 4 membahas tentang apa yang dilakukan pemerintah terhadap para simpatisan/ pendukung PKI di daerah-daerah. Dalam kegiatan ini Peserta didik mencari informasi dari berbagai sumber, salah satunya membaca buku Ilmu Pengetahuan Sosial kelas 9. Berdasarkan informasi yang diperoleh, peserta didik dalam kelompoknya mengerjakan Lembar Kerja yang diberikan guru, (d) mengolah data dan informasi, yaitu pelaksanaan diskusi kelompok (peserta didik berdialog, secara mendalam untuk saling membantu, memahami materi pelajaran dengan anggota kelompok kemudian mencatat hasil diskusi), guru berkeliling sambil memperhatikan kelompok yang memerlukan bantuan, (e) mengkomunikasikan, yaitu perwakilan kelompok mempresentasikan hasil diskusi kelompok masing-masing, peserta didik mendengar tanggapan guru terhadap hasil kerjanya, guru memberikan kuis atau pertanyaan kepada peserta didik, pada saat menjawab kuis tidak saling membantu. Ketiga, Kegiatan Penutup, yaitu: (a) guru bersama peserta didik membuat kesimpulan hasil pembelajaran, (b) guru memberikan tugas untuk membaca materi yang akan disajikan pada pada pertemuan selanjutnya, (c) guru menutup pelajaran dan mengucapkan salam.

Hasil observasi kemampuan komunikasi peserta didik pada siklus II terlihat pada tabel 2 berikut. 
Tabel 2 Kemampuan Komunikasi Peserta Didik Pada Siklus II

\begin{tabular}{|c|l|c|c|}
\hline No & $\begin{array}{l}\text { Keterampilan Komunikasi } \\
\text { Peserta Didik }\end{array}$ & Jumlah & $\begin{array}{c}\text { Persentasi } \\
\text { dari 32 } \\
\text { Peserta Didik }\end{array}$ \\
\hline A & $\begin{array}{l}\text { Kemampuan berkomunikasi } \\
\text { verbal }\end{array}$ & & \\
\hline 1. & Melakukan diskusi & 26 & $81 \%$ \\
\hline 2. & $\begin{array}{l}\text { Mempresentasikan hasil } \\
\text { diskusi }\end{array}$ & 26 & $81 \%$ \\
\hline 3 & Menyampaikan pendapat & 27 & $84 \%$ \\
\hline 4 & Menjawab pertanyaan & 27 & $84 \%$ \\
\hline 5. & $\begin{array}{l}\text { Menuliskan hasil akhir } \\
\text { diskusi }\end{array}$ & 27 & $84, \%$ \\
\hline 6. & $\begin{array}{l}\text { Menggunakan tata bahasa } \\
\text { yang baik }\end{array}$ & 25 & $78 \%$ \\
\hline 7. & $\begin{array}{l}\text { Pembicaraan singkat, jelas } \\
\text { dan mudah dimengerti serta } \\
\text { terdengar dengan jelas }\end{array}$ & 25 & $78 \%$ \\
\hline Rata-rata \% KB 1 & $\begin{array}{l}\text { Kemampuan Berkomunikasi } \\
\text { Nonverbal }\end{array}$ & $81,43 \%$ \\
\hline B. & 25 & $78 \%$ \\
\hline 8. & Melihat lawan bicara & $81 \%$ \\
\hline 9. & Ekpresi wajah yang ramah & 26 & $81 \%$ \\
\hline 10. & $\begin{array}{l}\text { Menggerakan tangan sesuai } \\
\text { kata-kata yang diucapkan. }\end{array}$ & 26 & $80,71 \%$ \\
\hline Rata-rata \% KB 2 & & \\
\hline Rata-rata \% KB 1 dan KB 2 & \\
\hline
\end{tabular}

Secara grafis dapat dilihat peningkatannya pada grafis 2 berikut.

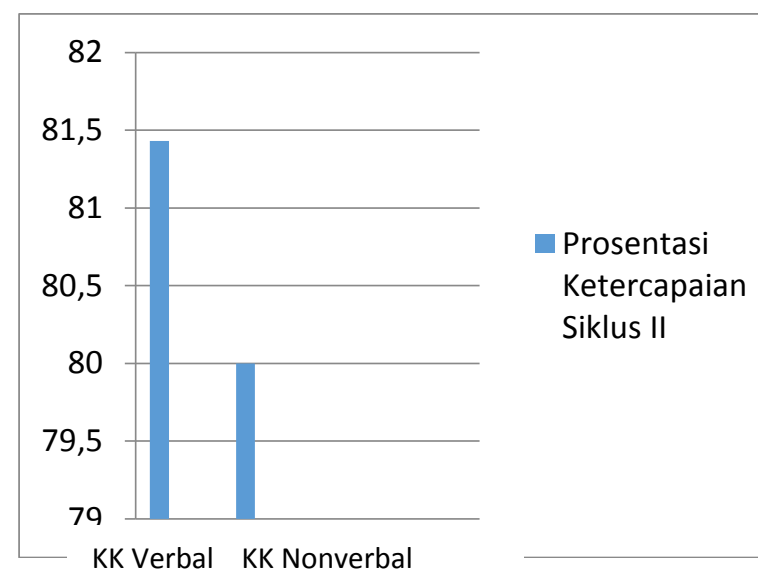

Hasil yang didapatkan dari proses pembelajaran dengan penerapan Cooperative Learning tipe STAD menunjukkan peningkatan dimana pada akhir siklus kedua ketercapaian kemampuan komunikasi peserta didik mencapai katagori baik $(80,71 \%)$ dengan keterlaksanaan penerapan model Cooperative Learning tipe STAD sesuai tahapannya, yaitu: presentasi kelas (class presentation),kerja kelompok (teams works), kuis (quizes),peningkatan nilai individu (individual improvement score), dan penghargaan kelompok (team recognation). Pencapaian tersebut telah memenuhi target penelitian, dengan demikian penelitian tindakan kelas ini dianggap berhasil, sehingga tidak dilanjutkan lagi pada siklus berikutnya. Berdasarkan hasil yang ada, maka penerapan Cooperative Learning tipe STAD dapat meningkatkan kemampuan komunikasi peserta didik dalam mata pelajaran Ilmu Pengetahuan Sosial.

Adapun dalam pembahasan ini, peneliti membahas dan membandingkan hasil-hasil penelitian siklus I dan siklus II sebagai berikut. Kemampuan komunikasi peserta didik pada siklus I, kemampuan komunikasi verbal ketercapaian rata-rata $66,43 \%$ dan kemampuan komunikasi nonverbal ketercapaian rata-rata 65\%. Sedangkap kemampuan komunikasi peserta didik siklus II, kemampuan komunikasi verbal ketercapaian rata-rata $81,43 \%$ dan kemampuan komunikasi nonverbal $80 \%$. Ini berarti bahwa kemampuan komunikasi verbal pada siklus II naik 15\% atau lebih baik dari pada siklus I. Kemampuan komunikasi nonverbal pada siklus II naik juga 15\% atau lebih baik dari dari pada siklus I. Rata-rata keseluruhan kemampuan komunikasi siklus I $65,72 \%$ dan kemampuan komunikasi siklus II $80,71 \%$ naik $15 \%$ atau lebih baik dari pada siklus I seperti tampak pada tabel 1.3 berikut.

Tabel 3

Perbandingan Kemampuan Komunikasi Peserta Didik Siklus I dan Siklus II

\begin{tabular}{|c|l|c|c|}
\hline No & $\begin{array}{c}\text { Komponen } \\
\text { Kemampuan } \\
\text { Komunikasi }\end{array}$ & Siklus I & Siklus II \\
\hline 1. & Komunikasi Verbal & $66,43 \%$ & $81,43 \%$ \\
\hline 2. & $\begin{array}{l}\text { Komunikasi } \\
\text { Nonverbal }\end{array}$ & $65 \%$ & $80 \%$ \\
\hline \multicolumn{2}{|c|}{ Rata-rata } & $65,72 \%$ & $80,71 \%$ \\
\hline
\end{tabular}

Perbandingan prosentasi rata-rata kemampuan komunikasi peserta didik pada siklus I dan siklus II dapat dilihat dalam grafik 3 berikut ini. 


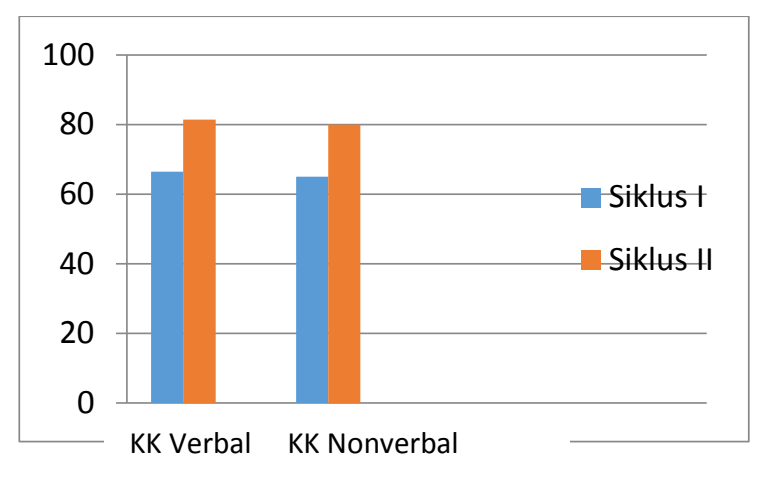

Gambar 1.3

Grafik Perbandingan Peningkatan Kemampuan Komunikasi Peserta Didik

Sejalan dengan itu, Slavin (2005: 141) menyatakan bahwa pengalaman kooperatif memang dapat lebih meningkatkan komponen perilaku kooperatif dan altruistik dibanding dengan pengalaman-pengalaman kompetitif atau individualistik. Cooperative Learning dapat mengembangkan perilaku semacam perilaku prososial yang semakin ditumbuhkan di dalam masyarakat di mana kemampuan berkomunikasi/bergaul dengan orang lain menjadi semakin krusial.

Selanjutnya, David dan Roger Johnson (2002) menyatakan bahwa dengan Cooperative Learning antar individu dan kelompok dibelajarkan keterampilan sosial, yaitu: kepemimpinan, pengambilan keputusan, membangun kepercayaan, komunikasi, dan kemampuan mengelola konflik.

\section{PENUTUP}

Berdasarkan temuan dan pembahasan hasil penelitian ini, simpulan yang dapat diambil adalah pembelajaran dengan menggunakan model Cooperative Learning tipe STAD dapat meningkatkan kemampuan komunikasi peserta didik, Pertama, kemampuan komunikasi verbal, yaitu: (1) melakukan diskusi, (2) mempresentasikan hasil diskusi, (3) menyampaikan pendapat, (4) menjawab pertanyaan, (5) menuliskan hasil akhir diskusi, (6) menggunakan tata bahasa yang baik, dan (7) pembicaraan singkat, jelas, dan mudah dipahami serta suara terdengar jelas, Kedua, kemampuan komunikasi nonverbal, yaitu: (1) melihat lawan bicara, (2) ekspresi wajah yang ramah, dan (3) gerakan tangan yang sesuai dengan kata-kata yang diucapkan.

Aktivitas belajar peserta didik dalam melaksanakan tahapan-tahapan Cooperative Learning tipe STAD mulai dari presentasi kelas, kerja kelompok, kuis, peningkatan nilai individu, dan penghargaan kelompok mulai dari siklus I ke siklus II dan pada akhirnya maksimal pada siklus II, yaitu hampir semua jenis aktivitas sudah tercapai.

Untuk itu, disarankan agar model Cooperative Learning tipe STAD ini tidak hanya digunakan dalam pembelajaran Ilmu Pengetahuan Sosial semata tetapi juga pada mata pelajaran lain dan tingkatan sekolah lainnya karena efektif dapat meningkatkan mutu proses dan hasil pembelajaran (sikap, pengetahuan, dan keterampilan) peserta didik.

\section{DAFTAR PUSTAKA}

Adisusilo, S. (2012). Pembelajaran Nilai-Karakter. Jakarta: PT Raja Grafindo Persada.

Anita, Lie. (2007), Cooperative Learning. Jakarta: PT Gramedia.

Darmadi, H. (2013). Dimensi-Dimensi Metode Penelitian Pendidikan dan Sosial: Konsep Dasar dan Implementasi. Bandung: Alfabeta.

Daryanto. (2011). Penelitian Tindakan Kelas dan Penelitian Tindakan Sekolah.Yogyakarta: Gavameda

David and Roger Johnson."Cooperative Learning" \{Online\}26 Desember 2019. (http://www.clcc.com/pages/cl.htlm/)

Hardjana, M. (2003). Komunikasi Intrapersonal dan Komunikasi Interpersonal. Yogyakarta: Kanisius.

Indradjati (2001). Menuju Masyarakat Belajar. Jakarta: Logos Wacana Ilmu.

Kementerian Pendidikan dan Kebudayaan. (2014). Modul Pelatihan Implementasi Kurikulum 2013. Jakarta: Kemendikbud.

Komalasari, K. (2010). Pembelajaran Kontekstual Konsep dan Aplikasi. Bandung: Aditama. 
Lickona, T. (2012). Educating for Character: How Our School Can Teach Respect and Responsibility: Terjemahan Wamaungo. Jakarta: PT Bumi Aksara

Nasution, S. (2004). Didaktik Asas-asas Mengajar. Bandung: Aksara.

Shoimin, A. (2018). 68 Model Pembelajaran Inovatif dan Kurikulum 2013. Yogyakarta: Ar-Ruzz Media
Slavin, RE. (2008). Cooperative Learning. Nusa Media: Bandung.

Sugiyono, (2013), Metode Penelitian Pendidikan (Pendekatan Kuantitatif, Kualitatif, dan R\&D). Bandung: CV Alfabeta

Undang-UndangNomor 20 Tahun 2003 tentang Sistem Pendidikan Nasional 